\title{
The Effect of UV-B Radiation on Bufo arenarum Embryos Survival and Superoxide Dismutase Activity
}

\author{
J. Herkovits ${ }^{1 *}$, J. L. D' Eramo $^{1}$ and O. Fridman ${ }^{1}$ \\ ${ }^{1}$ Programa de Seguridad Química, Instituto de Ciencias Ambientales y Salud, Fundación PROSAMA, Paysandú 752 \\ (1405), Buenos Aires, Argentina. Member of Consejo Nacional de Investigaciones Científicas y Técnicas (CONICET) de \\ la Argentina. \\ *Correspondence to Dr. Jorge Herkovits. Email: herkovit@mail.retina.ar
}

Received: 05 January 2006 / Accepted: 17 March 2006 / Published: 31 March 2006

\begin{abstract}
The exposure of Bufo arenarum embryos to 300-310 nm UV-B at a dose of 4,104 Joule $/ \mathrm{m}^{2}$ resulted in $100 \%$ lethality within $24 \mathrm{hr}$ while $820 \mathrm{Joule} / \mathrm{m}^{2}$ was the NOEC value for short-term chronic (10 days) exposure. The dose response curves show that lethal effects are proportional with the dose and achieve its highest value within $48 \mathrm{hr}$ post exposure. The superoxide dismutase (SOD) activity in amphibian embryos for sublethal UV-B exposures was evaluated by means of UV-B treatments with 273 (A), 820(B), 1368(C) and 1915(D) Joule $/ \mathrm{m}^{2}$ at 2 and 5 hours post irradiation. The SOD activity in units/mg protein in A, B, C and D at $2 \mathrm{hr}$ after treatments were $80.72 \pm 14.29,74.5 \pm 13.19,39.5 \pm 6.99$ and $10.7 \pm 1.89$ respectively while for control embryos it was $10.88 \pm$ 1.31. At $5 \mathrm{hr}$ after treatments the SOD values were similar to those found in control embryos. The results confirm the high susceptibility of amphibian embryos to UV-B and point out that the SOD activity is enhanced by low doses of UV-B irradiation achieving significantly higher values than in control embryos at $2 \mathrm{hr}$ post exposure.
\end{abstract}

Keywords: UV-B, Amphibian embryos, Superoxide dismutase

\section{Introduction}

Exposure to UV-B may result from both natural and artificial sources. The sun is the principal source of exposure for most people and wildlife. Decreases in stratospheric ozone levels from anthropogenic inputs of chlorinated fluorocarbons have resulted in an increased amount of harmful ultraviolet-B (UV-B, 280-315 nm) radiation, having serious consequences for living organisms. A $10 \%$ reduction in ozone could lead up to $15-20 \%$ increase in UV exposure [1]. The primary products generated by UV absorption are reactive species in a metastable excited state of free radicals such as superoxide. Dark chemical reactions then occur often within microseconds but they may last for hours, as in the case of the lipid peroxidation chain reaction. The ion superoxide induce peroxidation of fatty acids, affecting membrane lipids [2], provoke monobasic damage, strand breaks and reading frame shifting on DNA [3], e.g. denaturalization and/or degradation of proteins [4], and depolarization of polysaccharides [5]. The cellular consequences of damage due to UV radiation include changes in membrane permeability and membrane transport systems, activation of genes, mutation, inhibition of cell division, activation of viruses, etc., resulting in cellular death [6]. At high dose UV-B radiation enhance lipid peroxidation, a widely accepted general mechanism for cellular injury and death [7-9]. Photoreactivating enzymes activities (photolyase) are a common mechanism of protection against UV-B exposure [8,9]; in some organisms, photoreactivation is the most important mechanism for the repair of cyclobutane pyrimidine dimers (CBPDs) [10], which are major cytogenic and mutagenic photoproducts in the DNA.

One of the major classes of antioxidant enzymes characterized in eukaryotic cells is superoxide dismutase (SOD), a family of metalloenzymes which catalyzes the spontaneous dismutation of superoxide anion to hydrogen peroxide and molecular oxygen. SOD is widely distributed in aerobic organisms and plays an important role in the control of radical superoxide levels in the cellular compartments [10]. Most oxidative enzymes are present in the skin of vertebrates [6], and under low dose of UV-B radiation, cells can generate an adaptive response through the induction of these stress proteins. These 
enzymes represent the first line of defense of aerobic cells against the toxic effects of free radicals. It is noteworthy that in the case of high UV-B irradiation, which causes lethality within few hours after treatment, no changes in the SOD, was registered in Bufo arenarum embryos [11].

The populations of many amphibian species, in widely scattered habitats, appear to be in severe decline. There is no known single cause for the declines, but their widespread distribution suggests the involvement of global agents such as increased UV-B radiation $[12,13]$. Amphibians seems to be very The most susceptible to UV-B radiation at early life stages are the eggs and young forms producing that can suffer severe developmental abnormalities and effects on metamorphosis [13-15]. On the other hand the high susceptibility of amphibian embryos to various environmental pollutants [16-18] and their synergistic effects with UV-B radiation as in the case of $\mathrm{Ni}$ [19] could contribute significantly to the malformations and the worldwide decrease in amphibian population. In previous studies conducted with amphibian embryos the toxicity of various substances were reported as Toxicity Profile (TOP) curves by plotting concentration-response data for $\mathrm{LC}(\mathrm{EC})_{90}, \mathrm{LC}_{50}$ and $\mathrm{LC}_{10}$ for acute, short term chronic or even chronic exposure period. By this means isotoxicity curves were reported $[20,21]$. The main purpose of this study is to report the dose response curves for UV-B exposure in Bufo arenarum embryos, the $\mathrm{LC}_{10}, \mathrm{LC}_{50}$ and $\mathrm{LC}_{90}$ plotted as TOP curves up to 10 days post irradiation (that is chronic effects in the case of early life stages), and the SOD activity in control and UV-B treated embryos. The possibility to employ amphibian embryos for the evaluation of the adverse effects of both natural and artificial sources of UV will be discussed.

\section{Materials and Methods}

Adult Bufo arenarum captured in the surroundings of Buenos Aires City were purchased from a commercial suplice. The animals weighed 200-250 g and were housed in a dry tank at $18^{\circ} \mathrm{C}$. Ovulation of females Bufo arenarum was induced by means of i.p. injection of homologous hypophysis. Oocytes were fertilized in vitro with a sperm suspension prepared in AMPHITOX solution (AS) [22]. Triplicate groups of 10 individuals obtained from three couples of parents were maintained in AS until the complete operculum stage, (Stage 25) [23].

Irradiation was performed by placing the uncovered Petri dishes containing the embryos under an UV-B light (300-310nm) with $4,56 \mathrm{watt} / \mathrm{m}^{2}$ of irradiantia (UVP M20, UVP Inc Upland CA). Dose-response curves were evaluated by expressing triplicate groups of 10 embryos in $10 \mathrm{ml}$ of AS to 820,1368, 1915, 2460, 1730, 2730 3550 , and $4100 \mathrm{Joule} / \mathrm{m}^{2}$ and maintaining them in $40 \mathrm{ml}$ of AS during 10 days post irradiation. The duration of the UV-B exposures ranged from 3 to $15 \mathrm{~min}$. for the lowest and highest doses, respectively. Triplicate groups of 10 individuals maintained in AS under standard (nonUV-B) laboratory lighting were used as controls. Embryo survival was evaluated daily up to 10 days post exposure. Dead embryos were removed. Mortality of the experimental embryos was statistically analyzed by means of PROBIT reporting $\mathrm{LE}_{10}, \mathrm{LE}_{50}$, and $\mathrm{LE}_{90}$ from 24 to 240 $\mathrm{hr}$ and was plotted as TOPs (isotoxicity) curves.

SOD activity was measured in duplicate groups of 20 embryos treated with irradiations ranging between 273 and $1915 \mathrm{Joule} / \mathrm{m}^{2}$, which represent a range of irradiations causing no to little lethality. Embryos at 2 and $5 \mathrm{hr}$ post irradiation from each experimental group were kept in liquid nitrogen. For the determination of SOD activity, embryos were thawed and homogenized in potassium phosphate buffer $10 \mathrm{mM} \mathrm{pH} 7.0$ with $1 \mathrm{mM}$ EDTA. Homogenates were centrifuged $10 \mathrm{~min}$ at 10.000 rpm and SOD activity was determined in the supernatant. Assay was performed in triethanolaminediethanolamine buffer (75 mM, pH 7.4), containing 3.0 mM EDTA; 1,5 mM $\mathrm{MnCl}_{2}, 0,1 \mathrm{mM} \mathrm{NADH}$, and 1,0 $\mathrm{mM} \beta$-mercaptoethanol. Under these conditions $\mathrm{O}_{2}^{-}$is generated at a constant rate oxidizing the NADH. SOD inhibits this oxidation. An inhibition curve was obtained using various concentrations of supernatant. SOD activity was calculated as an $\mathrm{I}_{50}$ value, 1 unit being defined as the amount of enzyme that inhibits the oxidation of NADH by $50 \%$. Enzymatic activities were expressed as units/mg of proteins measured in the supernatant by Lowry s method [24]. All SOD values are means+/-SE. One way ANOVA followed by Tukey's test was performed with STATISTIX software. P values less than 0.05 were considered as significant.

\section{Results}

\section{UV-B Toxicity and TOP Curves}

Fig. 1 shows the dose response curves relating UVB exposure to lethality. $820 \mathrm{Joule} / \mathrm{m}^{2}, 300-310 \mathrm{~nm}$ UV$B$ radiation did not cause lethality in Bufo arenarum embryos up to 10 days post irradiation, whereas 2480 $\mathrm{Joule} / \mathrm{m}^{2}$ was the maximal dose at which no lethality occurred within the initial 24 hours post exposure. All treatments over $1368 \mathrm{Joule} / \mathrm{m}^{2}$ resulted in a progressive increase in lethality up to $4100 \mathrm{Joule} / \mathrm{m}^{2}$ which caused $100 \%$ of lethality within $24 \mathrm{hr}$.

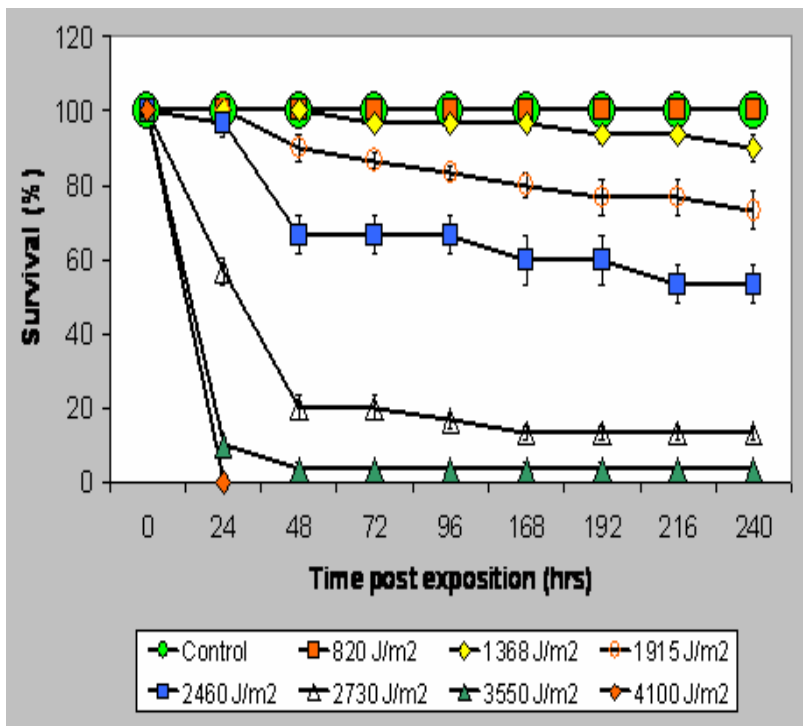

Figure 1: Dose response curves of UV-B radiation on Bufo arenarum embryos 
$\mathrm{LE}_{10}, \mathrm{LE}_{50}$, and $\mathrm{LE}_{90}$ values associated to the toxicity of UV-B on Bufo arenarum embryos from 24 to $240 \mathrm{hr}$ post irradiation are plotted in Fig. 2. The cumulative mortality post UV-B irradiation resulted in a reduction of the dose required to cause a given adverse effect as the time post irradiation is expanded. The $\mathrm{LE}_{50}$ values for 300-310 nm of wavelength decreased from 2891 to $2209 \mathrm{Joule} / \mathrm{m}^{2}$ of exposure. A similar pattern is observed for $\mathrm{LE}_{10}$ (from 2424 to $1529 \mathrm{Joule} / \mathrm{m}^{2}$ ) and $\mathrm{LE}_{90}$ (from 3445 to $3191 \mathrm{Joule} / \mathrm{m}^{2}$ ).

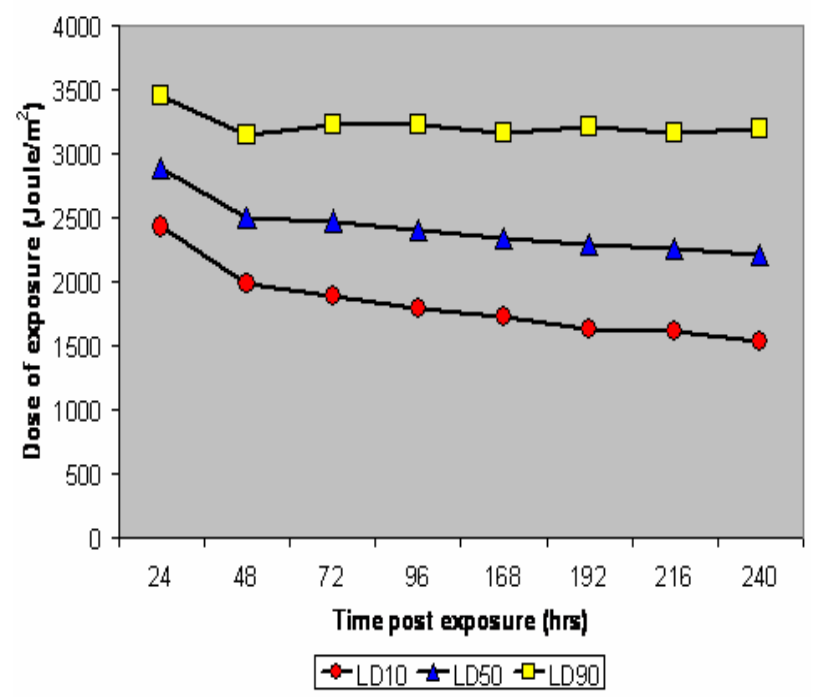

Figure 2: Top curves for UV-B in Bufo arenarum embryos

Table 1 shows that the intervals of confidence of $\mathrm{LE}_{50}$ do not overlap with those of $\mathrm{LE}_{10}$ and $\mathrm{LE}_{90}$. The NOEC value was approx. $820 \mathrm{Joule} / \mathrm{m}^{2}$, while the $\mathrm{LE}_{100} / 24 \mathrm{hr}$ post irradiation was approximately 4100 Joule $/ \mathrm{m}^{2}$.

Table 1: Lethal Exposition Toxicity and Intervals of Confidence of UV-B in Bufo arenarum embryos (Joule $/ \mathrm{m}^{2}$ )

\begin{tabular}{|c|c|c|c|}
\hline $\begin{array}{l}\text { Time post } \\
\text { exposition }(h r)\end{array}$ & $L E_{10}$ & $L E_{50}$ & $L E_{90}$ \\
\hline 24 & $\begin{array}{c}2424 \\
(2244-2553)\end{array}$ & $\begin{array}{c}2891 \\
(2768-3030)\end{array}$ & $\begin{array}{c}3462 \\
(3249-3778)\end{array}$ \\
\hline 48 & $\begin{array}{c}1979 \\
(1761-2124)\end{array}$ & $\begin{array}{c}2512 \\
(2359-2621)\end{array}$ & $\begin{array}{c}3134 \\
(2935-3478)\end{array}$ \\
\hline 72 & $\begin{array}{c}1892 \\
(1384-2151)\end{array}$ & $\begin{array}{c}2471 \\
(2184-2749)\end{array}$ & $\begin{array}{c}3227 \\
(2875-4210)\end{array}$ \\
\hline 96 & $\begin{array}{c}1783 \\
(1559-1946)\end{array}$ & $\begin{array}{c}2397 \\
(2250-2544)\end{array}$ & $\begin{array}{c}3224 \\
(2989-3609)\end{array}$ \\
\hline 168 & $\begin{array}{c}1728 \\
(1504-1889)\end{array}$ & $\begin{array}{c}2334 \\
(2184-2479)\end{array}$ & $\begin{array}{c}3153 \\
(2924-3230)\end{array}$ \\
\hline 192 & $\begin{array}{c}1630 \\
(1400-1796)\end{array}$ & $\begin{array}{c}2285 \\
(2127-2438)\end{array}$ & $\begin{array}{c}3205 \\
(2954-3615)\end{array}$ \\
\hline 216 & $\begin{array}{c}1611 \\
(1384-1777)\end{array}$ & $\begin{array}{c}2255 \\
(2097-2405)\end{array}$ & $\begin{array}{c}3156 \\
(2910-3571)\end{array}$ \\
\hline 240 & $\begin{array}{c}529 \\
(1299-1701)\end{array}$ & $\begin{array}{c}2206 \\
(2045-2364)\end{array}$ & $\begin{array}{c}3191 \\
(2927-3617)\end{array}$ \\
\hline
\end{tabular}

SOD activities determined in embryos treated with low UV-B levels are shown in Fig 3. The maximal SOD response was achieved between 273 and $820 \mathrm{Joule} / \mathrm{m}^{2} 2$ $\mathrm{hr}$ after irradiation. Slightly higher doses such as 1368 Joule $/ \mathrm{m}^{2}$ resulted in a minor response in SOD activity but still significantly higher than in control embryos. Higher doses (e.g. $1915 \mathrm{Joule} / \mathrm{m}^{2}$ ) resulted in similar SOD activity as in control embryos. Five hours after exposure, SOD activity did not exhibit any significant differences with respect to control embryos.

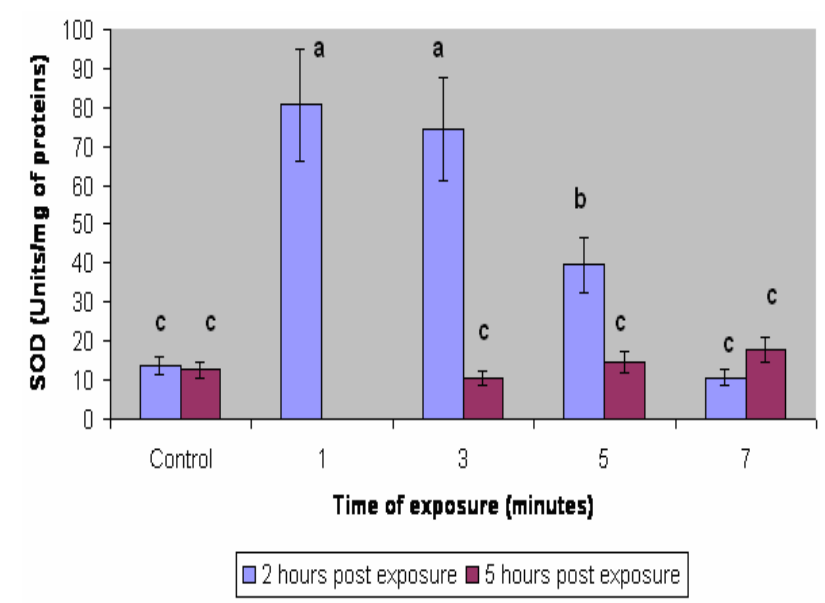

Figure 3: Effect of UV-B radiation on superoxide dismutase activity in Bufo arenarum embryos

\section{Discussion}

As a general pattern, the dose-response and isotoxicity - TOP curves - [20] of UV-B treated Bufo arenarum embryos point out a proportional increase in mortality as the irradiation is increased with a cumulative lethal effect observed mainly within the initial $48 \mathrm{hr}$ post exposure. In fact, the lethality observed in UV-B treated Bufo arenarum embryos increased only 1.31 times from 24 to $240 \mathrm{hr}$ post exposure. Therefore, in the case of doses of UV-B irradiation exerting acute lethality, the initial $48 \mathrm{hr}$ post exposure is the most critical period. This pattern of toxicity is similar to the adverse effects observed with some metals such as $\mathrm{Al}$ [20] and to some extent $\mathrm{Cu}$ [21] and $\mathrm{Cd}$ [25] in which it is not unusual to obtain around the same LC value during the initial $24 \mathrm{hr}$ and up to $168 \mathrm{hr}$ (short-term chronic) post exposure. Although in the case of metal toxicity the exposure condition is usually continuous, it is notwithstanding that based on uptake/tissue residue studies in amphibian embryos the plateau level is achieved for early developmental stages within one hr. after exposure [16].

Taking into account that in this study $1368 \mathrm{Joule} / \mathrm{m}^{2}$ of UV-B exerted only minimal lethal effects even after 10 days post exposure, it can be assumed that natural exposure to UV-B, that is around $1250 \mathrm{Joule} / \mathrm{m}^{2}$, have no lethal effects on Bufo arenarum embryos. The susceptibility of amphibian embryos and larvae to UV-B seems to vary significantly in different species. In fact, although the survival results for Bufo arenarum are in agreement with the data reported for Rana arvalis, Rana temporaria and Bufo.bufo [26], in the case of other 
anuran species such as, Rana pipiens, Rana clamitans and Rana septentrionalis, ambient levels of solar radiation were found to be lethal to all three species under exposure conditions that eliminated shade and refuge [13].

Amphibians have defenses against UV-B irradiation that can limit damage or repair it after exposure to this physical agent [27]. These include behavioral, physiological, and molecular defenses. These defenses differ interspecifically, with some species more able to cope with exposure to UV-B than others. The fact that Bufo arenarum pertains to the more resistant amphibian species to UV-B irradiation could be related to their dark pigmentation, a factor which could allow them to cope better than others in front of UV-B exposure. On the other hand, the highly significant increase in SOD activity in a wide range of sublethal irradiation conditions seems to be directly related to defense mechanisms against the oxidative stress exerted by UV$\mathrm{B}$ irradiation. It is noteworthy that in Bufo arenarum embryos and larvae SOD activity at $2 \mathrm{hr}$ post exposure increases about 8 times in a wide range of doses from 200 to $800 \mathrm{Joule} / \mathrm{m}^{2}$; while at higher levels which could already exert lethality in the most UV-B sensitive embryos, SOD activity only increased about 2 times compared with controls. Exposures exerting higher letal effects resulted in no increase in SOD activity at least during the time period evaluated. It is noteworthy that at $5 \mathrm{hr}$ post exposure in all experimental conditions SOD activity was found to recover to a similar level than in control embryos. These results point out that SOD activity could be related to active defense mechanisms against oxydative stress exerted by UV-B irradiation detectable in the case of sublethal exposure conditions. The high increase in SOD activity at $2 \mathrm{hr}$ post sublethal UV-B exposure could be used as a biomarker of UV-B irradiation in amphibian embryos. SOD activity as a result of acute or chronic UV irradiation seems to differ very markedly in different biological models. In human blood mononuclear cells was also found an enhancement of SOD activity after UV-B radiation to $270 \mathrm{Joule} / \mathrm{m}^{2}$ but the increase was limited to 1.3-1.5-fold after a $3 \mathrm{~h}$ dark incubation period [28]. However in most studies like in C57 BL6 mice skin exposed to acute or chronic UV-B irradiation, SOD activity decreased sharply reaching a minimum at $18 \mathrm{hr}$ after acute irradiation. [29]. In murine epidermis and the dermis after exposure to UV radiation (25 Joule/ $\mathrm{cm}^{2}$, UV-A+UV-B), superoxide dismutase activities reached a minimum at $3 \mathrm{~h}$ postexposure with a recovery in the epidermis by $12 \mathrm{~h}$ and in the dermis by $120 \mathrm{~h}$. [30]. It has been reported that ultraviolet radiation by generating reactive oxygen intermediates (ROIs) induces apoptosis. The acute lethality exerted by UV-B in amphibian embryos could be related to the apoptosis of a significant number of cells after high UV-B irradiation.

Due to the depletion of the stratospheric ozone, living organisms including humans are exposed to higher intensities of UV-B. On the other hand most artificial sources of UV, except for lasers, emit a spectral continuum of UV characteristic peaks, troughs and lines. These sources include various lamps used in medicine, industry, commerce, research and home. UV-induced biological effects depend on the wavelengths of the radiation. By summing the biologically effective irradiance over the exposure period, the biologically effective radiant exposure (Joule $/ \mathrm{m}^{2}$ effective) can be calculated. The most used quantity for describing the erythemal potential of an exposure to UV-B is the number of erythemal doses represented by the exposure of UV-B that produces an erythema on a previously unexposed skin. It correspond to a radiant exposure at the maximum spectral efficacy for erythema (around 300 $\mathrm{nm}$ ), of approximately 150 to $2000 \mathrm{Joule} / \mathrm{m}^{2}$ effective, about the same experimental conditions as conducted in this study. As $200-300 \mathrm{Joule} / \mathrm{m}^{2}$ effective is used as the value of 1 MED for comparative safety purpose for white skin, the fact that in Bufo arenarum embryos SOD activity at $2 \mathrm{hr}$ post exposure increases about 8 times in a wide range of doses from 200 to $800 \mathrm{~J} / \mathrm{m}^{2}$ could open the possibility to employ SOD activity, at least in this amphibian embryo, as an alternative test for erythema studies.

Acknowledgments: This work was supported by a grant PICT 03/14375 from Agencia Nacional de Promoción Científica y Tecnológica Argentina and Fundación PROSAMA. We thank Julie Brodeur for editorial assistance. Address correspondence to J. Herkovits, Instituto de Ciencias Ambientales y Salud, Fundación PROSAMA, Paysandú 752, 1405 Buenos Aires, Argentina.

\section{References}

1. Lesser, M. P.; Farrell, J. H.; Walker, C. W.: Oxidative stress, DNA damage and p53 expression in the larvae of Atlantic cod (Gadus morhua) exposed to ultraviolet $(290-400 \mathrm{~nm})$ radiation. $J$. Exp. Biol. 2001, 204, 157-164.

2. Barber, A. A.; Bernheim, F.: Lipid peroxidation: its measurement, occurrence, and significance in animal tissues. Adv. Gerontol. Res. 1967, 2, 355403.

3. Moody, C. S.; Hassan, H. M.: Mutagenicity of oxygen free radicals. Proc Natl. Acad. Sci. U S A. 1982, 79, 2855-9285.

4. Del Maestro, R.; Thaw, H. H.; Bjork, J.; Planker, M.; Arfors, K. E.: Free radicals as mediators of tissue injury. Acta. Physiol. Scand. Suppl. 1980, 492, 43-57.

5. McCord, J. M.: Free radicals and inflammation: protection of synovial fluid by superoxide dismutase. Science. 1974, 185, 529-531.

6. International Programme on Chemical Safety. Environmental Health Criteria 160. Ultraviolet Radiation. World Health Organization. 1994.

7. Desai, I. D.; Sawant, P. L.; Tappel, A. L.: Peroxidative and radiation damage to isolated lysosomes. Biochim. Biophys. Acta. 1964, 86, 277 285.

8. Putvinsky, A. V.; Sokolov, A. I.; Roshchupkin, D. I.; Vladimirov, Y. A.: Electric breakdown of bilayer phospholipid membranes under ultraviolet irradiation-induced lipid peroxidation FEBS Lett. 1979, 106, 53-55. 
9. Azizova, A. O.; Islomov, A. I.; Roshchupkin, D. I.; Predvoditelev, D. A.; Remizov, A. N.; Vladimirov, Y. A.: Free radicals formed on ultraviolet irradiation of the lipids of biological membrane. Biophysics 1980, 24, 407-414.

10. Sasaki, H.; Akamatsu, H.; Horio, T.: Effects of a single exposure to $\mathrm{UV}-\mathrm{B}$ radiation on the activities and protein levels of copper-zinc and manganese superoxide dismutase in cultured human keratinocytes. Photochem. Photobiol. 1997, 65, 707-713.

11. D'Eramo, J. L.; Fridman, O.; Herkovits, J.: Respuesta antioxidante en embriones de Bufo arenarum expuestos a dosis letales de radiación ultravioleta (UV-b). En: Toxicología y Química Ambiental. Contribuciones Para un Desarrollo Sustentable. Society of Environmental Toxicology and Chemistry. Pensacola, FL. USA. (J. Herkovits, Ed), 2003, pp. 147-149.

12. Blaustein, A. R.; Wake, D. B.: Declining amphibian populations: A global phenomenon? Trends Ecol. Evol. 1990, 5, 203-204.

13. Tietge, J. E.; Diamond, S. A.; Ankley, G. T.; DeFoe, D. L.; Holcombe, G. W.; Jensen, K.M.; Degitz, S. J.; Elonen, G. E.; Hammer, E.: Ambient solar UV radiation causes mortality in larvae of three species of Rana under controlled exposure conditions. Photochem. Photobiol. 2001, 74, 261-268

14. Blaustein, A. R.; Hoffman, P. D.; Hokit, D. G.; Kiesecker, J. M.; Walls, S. C.; Hays, J. B.: UV repair and resistance to solar UV-B in amphibian eggs: a link to population declines? Proc. Natl. Acad. Sci. U S A. 1994, 91, 1791-1795.

15. Crump, D.; Berril, M.; Coulson, D.; Lean, D. R. S.; McGillvray, L.; Smith, A.: Sensitivity of amphibian embryos, tadpoles and larvae to enhanced UV-B radiation in natural pond conditions. Can. J. Zool. 1999, 77, 1956-1966.

16. Perez-Coll, C. S.; Herkovits, J.: Stage dependent uptake of cadmium by Bufo arenarum embryos. Bull. Environ. Contam. Toxicol. 1996, 56, 663-669.

17. Herkovits, J.; Herkovits, F. D.; Pérez-Coll, C. S.: Lead Toxicity TOP and Time Dependent LeadZinc Antagonism in Bufo arenarum Embryos. Abstract Book of the $17^{\text {th }}$ Annual Meeting of the Society of Environmental Toxicology and Chemistry, Washington, DC, 1996, 17-21 November, p.141.

18. Perez-Coll, C.; Herkovits, J.: Lethal and teratogenic effects of naringenin evaluated by mean of an amphibian embryo toxicity test (AMPHITOX). Food Chem. Toxicol. 2004, 42, 299-306.
19. Herkovits, J.; Pérez-Coll, C. S.: AMPHITOX: A Standardized Set of Toxicity Tests employing Amphibian Embryos. It's Potential for Customized Hazard Assessment. In: Multiple Stressor Effects in Relation to Declining Amphibian Populations. ASTM (Linder G, Krest S, Sparling D, Little E. E., eds) ASTM International. 2003. 46-60.

20. Herkovits, J.; Herkovits, F. D.; Pérez-Coll, C. S.: Identification of aluminium toxicity and aluminiumzinc interaction in amphibian Bufo arenarum embryos. Environ. Sci. 1997, 5, 57-64.

21. Herkovits, J.; Helguero, L. A.: Copper toxicity and copper-zinc interactions in amphibian embryos. Sci. Total Environ. 1998, 221, 1-10.

22. Herkovits, J.; Perez-Coll, C.: Bioensayos para test de toxicidad con embriones de anfibio “ANFITOX“. basado en Bufo arenarum. Test Agudo (ANFIAGU), Crónico corto (ANFICOR), Crónico (ANFICRO) y de Estadios Tempranos del Desarrollo (ANFIEMB). Ingeniería Sanitaria y Ambiental. 1999, 42, 24-30 and 43, 50-55.

23. Del Conte, E.; Sirlin, L.: The first stages of Bufo arenarum development (in spanish). Acta Zool. Lilloana 1951, 12, 495-499.

24. Lowry, O. H.; Rosebrough, H. J.; Farr, A. I.; Randall, R. J.: Protein measurement with the Folin phenol reagent. J. Biol. Chem. 1951, 193, 265-275.

25. Herkovits, J.; Cardellini, P.: Pavanati, C.; Perez'Coll, C.S. Susceptibility of early life stages of Xenopus laevis to cadmium. Environ. Toxicol. Chem. 1977, 16, 312-316.

26. Pahkala, M.; Laurila, A.; Merila, J.: Effects of ultraviolet-B radiation on behaviour and growth of three species of amphibian larvae. Chemosphere. 2003, 51, 197-204.

27. Blaustein, A. R.; Belden, L. K.: Amphibian defenses against ultraviolet-B radiation. Evol. Dev. 2003, 5, 89-97.

28. Alvarez, S.; Boveris, A.: Antioxidant adaptive response in human blood mononuclear cells exposed to UV-B. J. Photochem. Photobiol. B. 1997, 38, 152-157.

29. Iizawa, O.; Kato, T.; Tagami, H.; Akamatsu, H.; Niwa, Y.: Long-term follow-up study of changes in lipid peroxide levels and the activity of superoxide dismutase, catalase and glutathione peroxidase in mouse skin after acute and chronic UV irradiation. Arch. Dermatol. Res. 1994, 286, 47-52.

30. Shindo, Y.; Witt, E.; Han, D.: Packer, L.: Doseresponse effects of acute ultraviolet irradiation on antioxidants and molecular markers of oxidation in murine epidermis and dermis. J. Invest. Dermatol. 1994, 102, 470-475. 